Огляди літератури, оригінальні дослідження, погляд на проблему, випадок з практики, короткі повідомлення УДК 611-018.74-06:616.126-008

DOI 10.11603/1811-2471.2019.V.I3.10507

\title{
РОЛЬ ДИСФУНКЦІї ЕНДОТЕЛІЮ У ФОРМУВАННІ ВАД КЛАПАНІВ СЕРЦЯ
}

\section{○Л. Я. Федонюк}

\author{
Тернопільський національний медичний університет імені І. Я. Горбачевського МОз України
}

РЕЗЮМЕ. На сьогодні встановлено, що ендотелій $\epsilon$ динамічною системою, яка може змінюватись, а її структурно-функціональні властивості тісно пов'язані з численними локальними, системними чинниками, а також із особливостями структурної організації. Пошкодження або активація ендотеліоцитів порушує нормальні регуляторні механізми та призводить до фенотипових змін, які загалом визначаються як ендотеліальна дисфункція. Ендотеліальна дисфункція - це порушення взаємовідношень між факторами, які підтримують гомеостаз та регулюють численні функції ендотелію.

Мета - навести сучасні відомості про структурно-функціональні властивості ендотелію та патогенез ендотеліальної дисфункції; висвітлити взаємозалежні впливи вазоактивних субстанцій ендотеліального походження, передусім оксиду азоту.

До найбільш значущих механізмів ендотеліальної дисфункції належить порушення метаболізму L-аргінін оксид азоту (NO), який є основною ефекторною молекулою, що продукується ендотеліоцитами. Зміни функції судинного ендотелію можуть бути наслідком як зменшення синтезу NO ендотеліальними клітинами, так і активацією процесів його деградації в умовах оксидативного стресу.

Порушення функціонального стану ендотелію описані при різноманітних патологічних станах, таких як атеросклероз, артеріальна гіпертензія, гіперхолестеринемія, хронічна серцева недостатність, цукровий діабет. Ендотеліальна дисфункція практично закономірно розвивається при ревматичних хворобах, а також при інфекційному ендокардиті, що $є$ однією з головних причин кардіоваскулярних ускладнень захворювань.

КлючовІ СлОВА: ендотелій; кровоносні судини; вади клапанів серця.

Вступ. Ендотелій - метаболічно активна тканина, якій притаманний гетероморфізм, про який судять, в основному, за морфологічними ознаками: різноманітна форма, розміри, рельєф поверхні клітин і шару, розташування органел, будова міжклітинних контактів, структура субендотелію [4]. Важливе первинне самостійне значення ендотелію для розвитку серцево-судинних захворювань зумовлено тим, що це найбільша паракринна та ендокринна залоза організму [33].

Ендотелій продукує безліч чинників, які забезпечують нормальний гомеостаз: стимулятори та інгібітори росту; вазорелаксанти та вазоконстриктори; про- і антитромботичні чинники; активатори та інгібітори фібринолізу; цитокіни, що ілюструє функціональну різноманітність ендотеліального моношару в нормальній фізіології. Клітини ендотелію беруть участь у процесах запалення, тромбоутворення, проліферації та ремоделювання судинної стінки, що, в свою чергу, має значний вплив на прогресування серцево-судинної патології $[3,17,19,21]$.

Інтактний ендотелій модулює тонус належних гладких м'язових клітин, підтримує неадгезивність поверхні просвіту судин, опосередковує гемостаз, проліферацію клітин, запальні та імунні механізми в судинній стінці. Ендотелій розглядається як центральний посередник взаємного обміну життєво важливою інформацією між серцево-судинною та імунною системами, а також як потужний самостійний ендокринний орган із па- ракринними функціями, що регулює судинний тонус, коагуляцію, міграцію та проліферацію клітин, бере участь у реакціях запалення, тканинній регенерації та фіброзі, визначає фільтраційну функцію нирок, дифузію води та іонів $[4,14,16,40]$.

На сьогодні встановлено, що ендотелій $\epsilon$ динамічною системою, яка може змінюватись, а її структурно-функціональні властивості тісно пов'язані з численними локальними, системними чинниками, а також особливостями структурної організації [4]. У різних ділянках судинної системи ендотеліоцити перебувають у неоднакових умовах гемодинаміки та метаболізму, тому вони відрізняються за формою, розмірами, властивостями ядра, цитоплазми, біохімічною специфікою, типами рецепторів, активністю ферментів, а також за орієнтацією відносно осі судин $[4,5]$.

В ендотеліоцитах містяться специфічні протеїни, які беруть участь у регуляції апоптозу, у процесах коагуляції, в антигенній презентації, а також ферменти глутатіон-S-трансфераза, лактатдегідрогеназа. Ендотеліальні клітини продукують інтерлейкіни, інтерферони та низку факторів - колонієстимулювальний, дозрівання тимоцитів, активації тромбоцитів і фібробластів, а на мембранах вони містять рецептори до IgG $[25,38]$.

Ендотелій здійснює пряму підтримку гомеостазу шляхом збереження динамічної рівноваги серед низки різноспрямованих процесів регуляції тонусу судин (вазодилатація/вазоконстрикція), анатомічної будови і ремоделювання судин (син- 
Огляди літератури, оригінальні дослідження, погляд на проблему, випадок з практики, короткі повідомлення

тез/інгібування факторів проліферації), місцевого запалення (синтезу протизапальних факторів, регуляції судинної проникності, процесів адгезії лейкоцитів), процесів гемостазу та тромболізису (синтез та інгібування факторів агрегації тромбоцитів і фібринолізу). Цей цілеспрямований вплив реалізується за рахунок гормональної реакції ендотеліальних клітин на зміни швидкості кровотоку, тромбоцитарні медіатори (серотонін, АДФ, тромбін) та циркулюючі та/або тканинні нейрогормони (катехоламіни, вазопресин, ацетилхолін, ендотелін, брадикінін, гістамін).

У нормі у відповідь на ці стимули клітини ендотелію реагують посиленням синтезу ряду речовин, що призводить до розслаблення гладких м'язових клітин судинної стінки. Найважливішим серед цих чинників $\epsilon$ NO, що забезпечує вазодилатацію, гальмування експресії молекул адгезії та агрегацію тромбоцитів, і має антипроліферативну, антиапоптичну та антитромботичну дії.

Крім NO, до інших вазодилатаційних чинників, що утворюються в ендотелії, належать: простациклін, ендотеліальний фактор гіперполяризації, натрійуретичний пептид С-типу тощо. Вважають, що дія цих факторів стає важливим чинником регуляції судинного тонусу при зниженні рівня NO. До основних ендотеліальних вазоконстрикторів відносять ЕТ-1, серотонін і продукти циклооксигеназного шляху перетворення: простагландин $\mathrm{H} 2$ (ПГН2) і тромбоксан А2. Одними з найбільш вазоактивних речовин $є$ ендотеліальні пептиди. Це група біологічно активних пептидів широкого спектра дії, які $є$ найважливішими регуляторами функціонального стану ендотелію, морфологічно сполученими з кров'ю і м'язовою стінкою судин. Найвідоміший і вивчений з ендотелінів - ЕТ-1 - $\epsilon$ великим біциклічним поліпептидом, що складається з комбінації 21 амінокислоти. ЕТ-1 здебільшого утворюється в ендотеліальних клітинах, але, на відміну від інших ЕT (ЕT-2, ЕT-3), може синтезуватися в гладких м'язових клітинах судин, нейронах, астроцитах, ендометрії, гепатоцитах, тканинних базофілах. Синтез ЕТ-1 стимулюється тромбіном, адреналіном, ангіотензином, інсуліном, інтерлейкіном, клітинними факторами росту тощо. До інгібіторів синтезу ЕT-1 належать натрійуретичні пептиди. ЕТ-1 активує рецептори гладких м'язових клітин, стимулюючи стійку вазоконстрикцію і проліферацію середньої оболонки дрібних судин. ЕT-1 у 100 разів активніший, ніж ATII.

ЕT-1 чинить безпосередній констрикторний вплив на стінку як артерій, так і вен. У дослідженнях установлено, що після внутрішньовенного введення ЕT-1 спостерігається зниження коронарного кровотоку на 90 \%. ЕТ-1 чинить антинатрійуретичний ефект унаслідок констрикції артерій клубочків нирки, бере участь у автопаракринному контролі секреції альдостерону, адреномедуліну і вазопресину.

До інших вазоконстрикторних агентів належать ATII, тромбоксан A2, простагландин F2a, які безпосередньо діють на гладкі м'язові клітини.

Ендотелій $є$ важливим фактором регулювання коронарного судинного тонусу шляхом утворення й вивільнення вазодилататорних і вазоконстрикторних речовин, зокрема NO i ET-1.

Під впливом вазоактивних цитокінів на ендотеліоцитах збільшується експресія адгезивних молекул для нейтрофілів, лімфоцитів і моноцитів, що сприяє проникненню цих клітин через базальну мембрану та впливу на запальні процеси. В умовах активації прозапальними цитокінами клітинами ендотелію синтезується Е-селектин. Адгезовані лейкоцити вивільняють низку цитотоксичних медіаторів (вільні радикали кисню, протеолітичні ферменти), що негативно впливають на ендотелій і сприяють змінам функції ендотеліоцитів.

Пошкодження або активація ендотеліальної клітини порушує нормальні регуляторні механізми та призводить до фенотипових змін (дисбаланс між релаксаційними та констрикторними чинниками, антикоагулянтними та прокоагулянтними медіаторами, промоторами та інгібіторами росту), які загалом визначаються як ендотеліальна дисфункція $[9,14,16,29]$. В артеріальній стінці певні наслідки ендотеліальної дисфункції прямо співвідносяться з патофізіологією атеросклерозу і проявляються реактивністю судин і ангіоспазмом; підвищенням проникності для ліпопротеїнів; порушенням регуляції росту клітин судинної стінки (зниження регенерації ендотелію та посилення проліферації гладких м'язових клітин); зрушеннями гемостатичного/фібринолітичного балансів (сприяючи генерації тромбіну, відкладанню тромбоцитів і фібрину) [24, 28, 37, 42].

Вважають, що різні ангіоспастичні стимули можуть призводити до ендотеліальної дисфункції з дисбалансом активних судинних медіаторів, які відповідають за підтримку нормального ангіотонусу [28]. Ці самі фактори можуть викликати й порушення антитромбогенної активності стінки судин шляхом порушення клітинного метаболізму та виснаження енергетичних запасів.

Основними стимулами ендотеліальної дисфункції $є$ активація ендотелію цитокінами, гіперхолестеринемія та окиснення ліпопротеїнів [11, 21]. До теперішнього часу не існує певних пояснень механізмів ліпід/цитокін-опосередкованої дисфункції ендотелію, але припускають, що вони можуть бути оксидативної та неоксидативної природи [34]. 
Огляди літератури, оригінальні дослідження, погляд на проблему, випадок з практики, короткі повідомлення

у разі тривалого впливу пошкоджувальних факторів - гіпоксії, токсинів, імунних комплексів, медіаторів запалення, гемодинамічного перевантаження - відбуваються персистентна активація або пошкодження ендотеліоцитів, які призводять до патологічної відповіді навіть на звичайні стимули тромбоутворенням і клітинною проліферацією $[12,18]$. Реакцією організму у відповідь на гемодинамічне перевантаження $\epsilon$ активація циркулюючих ендотеліоцитоподібних стовбурових клітин кісткового мозку внаслідок ініціації процесів їх проліферації, міграції та диференціювання у функціонально повноцінні ендотеліоцити $[6,23]$. Такі стовбурові клітини здатні полегшувати репарацію ендотелію в процесі ангіоґенезу in vivo.

До найбільш значущих механізмів ендотеліальної дисфункції належить порушення метаболізму L-аргінін - оксид азоту (NO), який є основною ефекторною молекулою, що продукується ендотеліоцитами. Зміни функції судинного ендотелію можуть бути наслідком як зменшення синтезу NO ендотеліальними клітинами, так і активації процесів його деградації в умовах оксидативного стресу [16, 39].

NO належить до нестабільної хімічної структури, яка походить від неактивних будівельних частинок - ненасиченої жирної арахідонової кислоти та лужної амінокислоти L-аргініну. Критичним моментом є окиснення цих субстратів діоксигеназами - циклооксигеназою (ЦОГ) і білком ендотеліальної синтази NO (NOS). Вони виступають як конститутивні ферменти, а також як ензими, індуковані цитокінами або ендотоксинами [10, 27]. Показано, що NO взаємодіє з двовалентним залізом простетичних груп ЦОГ. NO чинить антипроліферативну дію на гладкі м'язові клітини судинної стінки та пригнічує адгезію нейтрофілів до ендотелію судин [26, 36].

Ендотеліальна дисфункція $\epsilon$ порушенням взаємовідношень між факторами, які підтримують гомеостаз та регулюють численні функції ендотелію. Порушення функціонального стану ендотелію описані при різноманітних патологічних станах, таких як атеросклероз, артеріальна гіпертензія, гіперхолестеринемія, хронічна серцева недостатність, цукровий діабет $[1,7,15,31]$. При цьому встановлено, що дисфункція ендотелію виявляється вже на початкових стадіях захворювання.

Ендотеліальна дисфункція практично закономірно розвивається при ревматичних хворобах, що $є$ однією з головних причин кардіоваскулярних ускладнень захворювань [8]. Ендотелію належить першочергова роль в ураженні клапанного апарату при хронічній ревматичній хворобі серця (PXC): вважають, що локальна ендотеліальна дисфункція, яка розвивається, сприяє формуванню вади клапана серця. Розвиток ендокардиту пов'язують із процесами аутоімунного пошкодження ендотелію та подальшими мембранними відповідями клітин. При ревматичних вадах серця ендотеліальна дисфункція сприяє утворенню тромбів на клапанах, склерозуванню їх стулок і півмісяцевих заслінок, посиленню легеневої гіпертензії [32].

За допомогою електронної мікроскопії мітрального клапана встановлено, що пошкодження ендотелію асоціюється з тяжкістю змін субендотеліальних колагенових волокон, причому більш чіткий зв'язок стосується поверхні, оберненої в бік шлуночка серця. За допомогою методів гістохімії та атомної фізико-хімічної абсорбційної спектроскопії досліджено морфологічні та мінералогічні властивості клапана аорти серця у хворих на РХС і виявлено зв'язок фіброзних змін, відкладень кристалів гідроксиапатитів і мікротромбозів із ендотеліальною дисфункцією.

Нині при різних ревматичних захворюваннях все більшу увагу привертає обмін NO. Імунні стреси, зумовлені дією цитокінів у таких хворих, стимулюють синтез NO [10]. Під впливом імуногенних стимулів ( $\gamma$-інтерферон, фактор активації тромбоцитів тощо) при ревматичних хворобах відбувається експресія гена, який відповідає за синтез індуцибельної NOS. При цьому макрофаги, нейтрофіли, моноцити, гепатоцити, фібробласти тощо продукують і виділяють упродовж багатьох годин у тисячу разів більше NO, ніж після стимуляції конститутивної NOS. У цих випадках NO сприяє імунному захисту організму, відіграючи роль імунорегулятора. У високих концентраціях NO виявляє не регуляторну, а цитостатичну (цитотоксичну) дію, що призводить до збільшення різних проявів аутоімунного характеру. Нітрування білків за участю NO у хворих на хронічну PXC збільшує їх антигенність, що сприяє аутоімунним процесам [35].

При гострій ревматичній лихоманці та хронічній РХС судини $\epsilon$ органом-мішенню та ареною розвитку патологічного процесу. На відміну від атеросклеротичного ураження, характер судинної патології різноманітний та включає різні форми ангіо- та васкулопатій, васкулітів і тромбоваскулітів, облітеруючі зміни судин з розвитком виразково-некротичних ускладнень, ішемії та некрозів [13]. Переважання ураження дрібних судин, артеріол і капілярів, порушення функціонування системи мікроциркуляції, зумовлене як змінами власне судинної стінки зі звуженням просвіту, так і внутрішньосудинними порушеннями реологічних властивостей крові. Ґенез ураження при ревматичних хворобах значною мірою зумовлений імунними порушеннями з унікальним набором 
Огляди літератури, оригінальні дослідження, погляд на проблему, випадок з практики, короткі повідомлення

специфічних антитіл та імунних комплексів, широким спектром молекулярно-клітинних реакцій за активної участі ендотелію, гладких м'язових клітин, клітин крові, відповідних медіаторів і лігандних систем (ендотелінів, цитокінів, молекул адгезії, NO) [20].

Нестача синтезу NO внаслідок порушення функції ендотелію при РХС може призводити до підвищення опору периферійних судин. Крім цього, запальні стимули сприяють синтезу індуцибельної NOS та її активації в багатьох клітинах і тканинах. Як наслідок цього, генерується велика кількість NO, яка набагато перевищує його фізіологічні кількості, що виробляються конститутивною NOS. Результатом цього процесу $є$ вазодилатація, яка призводить до появи гіперемії та набряку - характерних ознак запального ревматичного процесу.

В неекстремальних умовах гіперпродукція $\mathrm{NO}$, зумовлена індукованою NOS, може чинити на тканини захисну сприятливу дію, оскільки розширення судин поліпшує тканинну перфузію, інгібування адгезії та агрегації тромбоцитів. Послаблення синтезу NO при РXC сприяє підвищенню судинного тонусу, роблячи тим самим значний внесок у розвиток васкулопатій [35].

Регіонарна ішемія призводить до внутрішньосудинної активації лейкоцитів з їх адгезією на ендотелії. Гіперактивація нейтрофілів у судинному руслі вогнища ішемії для прогресування дисциркуляції не тільки є важливою сама собою за рахунок адгезії/агрегації клітин, блокади ними мікросудин, а й призводить до додаткового порушення захисного механізму, який підтримує нормальний кровообіг через прискорене руйнування NO, що вивільняється з ендотелію. Цей фактор, на додаток до фонового зниження активності NOсинтезуючих систем, може поглиблювати ступінь дисциркуляції.

Процеси ендотеліальної дисфункції з ураженням клапанів серця при інфекційному ендокардиті (IE) перебігають за участю цитокінів і трансмембранного хемокіну, який індукує синтез $\gamma$-інтерферону та активацію молекул клітинної адгезії, а, отже, прилипання до стулок клапанного апарату Т-супресорів з розвитком імунного запалення [2, 33]. Такі зміни посилюються у хворих із вторинним IE. У ін'єкційних наркоманів навіть без інфекційного ендокардиту розвивається ендотеліальна дисфункція тристулкового клапана, яка вважається добрим підґрунтям для подальшого формування вегетацій.

За допомогою стимуляції молекул клітинної адгезії при IE депозицію фібрину на ендотелії клапанів серця викликає бактеріальна інфекція. Крім метастатичної гематогенної бактеріальної ембо- лізації та імунокомплексного запального каскаду, в розвитку IE важливе значення відіграє ендотеліальна дисфункція, яка $є$ наслідком формування протиендотеліальних антитіл. IE, спричинений Staphylococcus aureus, Staphylococcus epidermidis, Staphylococcus sanguis, Streptococcus viridans, Streptococcus bovis, Escherichia coli, Enterococcus faecalis, Bartonella species тощо, викликає посилений апоптоз ендотеліоцитів і ознаки ендотеліальної дисфункції. Стафілококова інфекція більшою мірою здатна пошкоджувати ендотелій клапанного апарату.

При стрептококовій природі IE пошкодження ендотелію відбувається вже на найбільш ранніх стадіях захворювання, що $є$ відправною точкою в подальших морфологічних змінах патологічного процесу. За даними А. А. Quyyumi, при експериментальному IE інфекція Staphylococcus aureus сприяє змінам активності фібронектинзв' язувального протеїну, що викликає посилення формування вегетацій на клапанах і ураження ендотеліальних клітин. За допомогою ацетилсаліцилової кислоти при стафілококовому експериментальному IE зменшується синтез фібронектину та а-гемолізину з подальшим покращенням ендотеліальної функції. Існує прямий кореляційний зв'язок між рівнем бактеріємії у хворих на IE та концентрацією прозапальних цитокінів у крові, які відображають ступінь ендотеліальної дисфункції.

Ендотелій відіграє значну роль у регулюванні судинної архітектоніки, і довготривалі зміни гемодинамічного стресу можуть опосередкувати судинне ремоделювання [12, 30]. У цей процес втягується перебудова компонентів судинної стінки, тобто ендотеліальних і гладких м'язових клітин, колагенового матриксу. Два головних ендотеліальних фактори мають виражений ефект в цьому процесі: NO, який інгібує ліпоґенез і проліферацію гладких м'язових клітин, і ендотелін, що $\epsilon$ мітогенним і активує експресію протионкогену в судинних гладких м'язових клітинах. Можливо, що протизапальні цитокіни, ангіотензин II і норадреналін сприяють судинному ремоделюванню. Ці фактори стимулюють утворення активних форм металопротеаз - ферментів, які втягуються в руйнування судинного внутрішньоклітинного матриксу. Однак, внесок структурного ремоделювання та зниження еластичності невеликих судин у прогресування судинного ураження все ще залишається нез'ясованим.

Висновок. Розташування ендотелію між кров'ю та належними структурами серця та стінки судин визначає його унікальність та стратегічну важливість займаної позиції. Гетероморфізм будови ендотелію визначається його органоспецифічністю, а також відмінностями у функціо- 
Огляди літератури, оригінальні дослідження, погляд на проблему, випадок з практики, короткі повідомлення

нальному та метаболічному стані клітин. Ендотелій $\epsilon$ найважливішим регулятором гомеостазу, i його дисфункція відіграє істотну роль у формуванні вад клапанів серця.

Перспективи подальших досліджень. Подальше вивчення складних взаємодій між NO та ендотеліальною дисфункцією може стати терапевтичною стратегією, спрямованою на покращення ендотеліальної функції, або на забезпечення альтернативного джерела NO, що має на меті зниження випадків серцево-судинних захворювань.

\section{ЛІТЕРАТУРА}

1. Аронов Д. М. Некоторые аспекты патогенеза атеросклероза / Д. М. Аронов, В. П. Лупанов // Атеросклероз и дислипидемии. - 2011. - № 1. - С. 49-56.

2. Асташев П. Маркеры эндотелиальной дисфункции как прогностический признак течения внутрисердечного инфекционного процесса / П. Асташев, В. Гудымович // Вестник Национального медико-хирургического Центра им. Н. И. Пирогова. - 2011. - Т. 6, № 3. - С. 3-8.

3. Беленков Ю. Н. Ремоделирование сосудистого русла у больных артериальной гипертонией: возможности диагностики и коррекции / Ю. Н. Беленков, Е.В.Привалова, Ю. А. Данилогорская // Кардиология. 2012. - № 6. - С. 67-72.

4. Виноградов О. О. Структура й функції ендотелію: історичний аспект проблеми / О. О. Виноградов // Вісник Луганського національного університету імені Тараса Шевченка. - 2013. - Т. 6 (265), Ч. ІІ. - С. 72-80.

5. Возна В. Ендотелій: функціональні властивості та його дисфункція / В. Возна, К. Москалюк // Інфекційні хвороби. - 2015. - № 1. - С. 66-71.

6. Дєльцова О. Стовбурові клітини стінки кровоносних судин / О. Дєльцова, С. Геращенко, Ю. Чайковський // Український кардіологічний журнал. - 2014. № 1. - С. 97-101.

7. Загидуллин Н. Ш. Значение дисфункции эндотелия при сердечно-сосудистых заболеваниях и методы ее медикаментозной коррекции / Н. Ш. Загидуллин, К. Ф. Валеева, Н. Гассанов // Кардиология. - 2010. № 5. - C. 54-60.

8. Заремба $€$. Ендотеліальна дисфункція у хворих на ревматизм із недиференційованою дисплазією сполучної тканини / Є. Заремба, О. Зімба // Український ревматологічний журнал. - 2009. - № 4 (38). - С. 32-34.

9. Капелько В. И. Диастолическая дисфункция / В. И. Капелько // Кардиология. - 2011. - № 1. - С. 79-90.

10. Кетлинский С. А. Цитокины / С. А. Кетлинский, А. С. Симбирцев. - СПб. : Фолиант, 2008. - 552 с.

11. Люсов В. А. Уровень оксида азота в сыворотке периферической крови больных с различной тяжестью артериальной гипертензии / В. А. Люсов, В. А. Метельская, Р. Г. Оганов // Кардиология. - 2011. - № 12. C. 23-28.

12. Малая Л. Эндотелиальная дисфункция при патологии сердечно-сосудистой системы / Л. Т. Малая, А. Н. Корж, Л. Б. Балковая. - Харьков : Торсинг, 2002. 432 c.

13. Эндотелиальная дисфункция сосудов и ее коррекция при хронической ревматической болезни сердца / Л. Максимова, И. Мильнер, В. Толстой, И. Левада // Актуальні проблеми сучасної медицини. - 2008. - Т. 8, 4 (52). - С. 121-124.
14. Малярська Н. Ендотеліальна дисфункція як універсальний предиктор розвитку серцево-судинної патології та можливості ії корекції в практиці сімейного лікаря / Н. Малярська, М. Калініченко // Ліки України. 2017. - № 1 (207). - С. 38-41.

15. Палеев Ф. Н. Изменение интерлейкина-6 при различных формах ишемической болезни сердца / Ф. Н. Палеев // Кардиология. - 2010. - № 2. - С. 69-72.

16. Садляк О. В. Ендотелій як регулятор імунних, запальних та вільнорадикальних процесів, опосередкованих системою L-аргінін-оксид азоту / O. B. Садляк // Медична хімія. - 2013. - Т. 15 (4). - С. 96-99.

17. Садыкова Д. Значение дисфункции эндотелия при артериальной гипертензии у детей и подростков / Д. Садыкова, Е. Сергеева, Г. Афлятумова // Практическая медицина. - 2014. - № 9 (85). - С. 24-27.

18. Зміни ендотеліоцитів капілярів та гістологічної структури ішемізованої та інтактної м'язової тканини після трансплантації гемопоетичних стовбурових клітин фетальної печінки людини в експерименті in vivo / Р. Салютін, Д. Домбровський, С. Паляниця [та ін.] // Буковинський медичний вісник. - 2013. - Т. 17, № 1 (65). - С. 101-105.

19. Сукманова И. А. Показатели функции эндотелия, морфофункциональные параметры сердца и метаболический статус при диастолической хронической сердечной недостаточности у больных разных возрастных групп / И. А. Сукманова, Д. А. Яхонтов, Т. И. Поспелова // Кардиология и сердечно-сосудистая хирургия. - 2010. Т. 3, № 3. - С. 72-75.

20. Такташов Г. С. Роль эндотелиальной дисфункции сосудов при нарушениях респираторных функций у больных хронической ревматической болезнью сердца / Г. С. Такташов // Актуальні проблеми сучасної медицини. - 2015. - Т. 15, № 4 (52). - С. 120-124.

21. Шляхов Н. В. Судинний ендотеліальний фактор росту як маркер судинних дисфункцій у дітей 3 ожирінням / Н. В. Шляхов, О. А. Будрейко, С. О. Чумак // Проблеми ендокринної патології. -2012. - № 1. C. 26-32.

22. Amir O. Circulating interleukin-10: association with higher mortality in systolic heart failure patients with elevated tumor necrosis factor-alpha / O. Amir // Isr. Med. Assoc. J. - 2010. - Vol. 12 (3). - P. 158-162.

23. A novel method for the extraction and culture of progenitor stem cells from human peripheral blood for use in regenerative medicine / G. I. Punshon, D. S. Vara, K. M. Sales, A.M. Seifalian // Biotechnol. Appl. Biochem. 2011. - Vol. 55 (8). - P. 328-334.

24. Cardiovascular risk assessment beyond systemic coronary risk estimation: a role for organ damage markers / 
Огляди літератури, оригінальні дослідження, погляд на проблему, випадок з практики, короткі повідомлення

M. Volpe, A. Battistoni, G. Tocci [et al.] // J. Hypertens. 2012. - Vol. 30. - P. 1056-1064.

25. Dignat-George $\mathrm{F}$. The many faces of endothelial microparticles / F. Dignat-George, C. M. Boulanger // Arteriosclerosis, Thrombosis, and Vascular Biology. - 2011. Vol. 31 (1). - P. 27-33.

26. Feletou M. Nitric oxide: orchestrator of endothelium-dependent responses / M. Feletou, R. Kohler, P. M. Vanhoutte // Ann. Med. - 2012. - Vol. 44. - P. 694-716.

27. Forstermann U. Nitric oxide synthases: regulation and function / U. Forstermann, W. C. Sessa // Eur. Heart J. 2012. - Vol. 33. - P. 829-837.

28. Higashi Y. Endothelial dysfunction and hypertension in aging / Y. Higashi, Y. Kihara, K. Noma // Hypertens. Res. - 2012. - Vol. 35. - P. 1039-1047.

29. Hirata Y. Diagnosis and treatment of endothelial dysfunction in cardiovascular disease / Y. Hirata, D. Nagata, E. Suzuki // Int. Heart J. - 2010. - Vol. 51 (1). - P. 1-6.

30. Home measurement of blood pressure and cardiovascular disease: systematic review and meta-analysis of prospective studies / A. M. Ward, O. Takahashi, R. Stevens, C. Heneghan // J. Hypertens. - 2012. - Vol. 30. - P. 449-456.

31. Gut hormones and endothelial dysfunction in patients with obesity and diabetes / M. Iantorno, U. Campia, N. Di Daniele [et al.] // Int. J. Immunopathol. Pharmacol. 2014. - Vol. 27 (3). - P. 433-436.

32. Clinical spectrum of rheumatic fever and rheumatic heart disease: a 10 year experience in an urban area of South India / N. Joseph, D. Madi, G. S. Kumar [et al.] // N. Am. J. Med. Sci. - 2013. - Vol. 5 (11). - P. 647-652.

33. Leask R. L. Endothelium and valvular diseases of

\section{REFERENCES}

1. Aronov, D.M., \& Lupanov, V.P. (2011). Nekotoryye aspekty patogeneza ateroskleroza [Some aspects of the pathogenesis of atherosclerosis]. Ateroskleroz $i$ dislipidemii - Atherosclerosis and Dyslipidemia, 1, 49-56 [in Russian].

2. Astashev, P., \& Gudymovich, V. (2011). Markery endotelialnoy disfunktsii kak prognosticheskiy priznak techeniya vnutriserdechnogo infektsionnogo protsessa [Markers of endothelial dysfunction as a prognostic sign of the course of intracardiac infectious process]. Vestnik Natsionalnogo mediko-khirurgicheskogo Tsentra im. N.I. Pirogova-Bulletin of the National Medical and Surgical Center by N.I. Pirogov, 6, 3, 3-8 [in Russian].

3. Belenkov, Yu.N., Privalova, Ye.V., \& Danilogorskaya, Yu.A. (2012). Remodelirovaniye sosudistogo rusla u bolnykh arterialnoy gipertoniyey: vozmozhnosti diagnostiki i korrektsii [Remodeling of the vascular bed in patients with arterial hypertension: possibilities for diagnosis and correction]. Kardiologiya - Cardiology, 6, 67-72 [in Russian].

4. Vynohradov, O.O. (2013). Struktura i funktsii endoteliiu: istorychnyi aspekt problemy [Structure and functions of the endothelium: a historical aspect of the problem]. Visnyk Luhanskoho natsionalnoho universytetu imeni Tarasa Shevchenka - Bulletin of Luhansk Taras Shevchenko National University, 6 (265), II, 72-80 [in Ukrainian].

5. Vozna, V., \& Moskaliuk, K. (2015). Endoteliy: funktsionalni vlastyvosti ta yoho dysfunktsiia [Endothelium: the heart / R. L. Leask, N. Jain, J. Butany // Microsc. Res. Tech. - 2009. - Vol. 60 (2). - P. 129-137.

34. Meera K. S. Endothelial dysfunction and oxidative stress in hypertension / K. S. Мeera, S. R. Marcus // Asian. J. Med. Res. - 2012. - No. 1 (3). - P. 84-89.

35. Nitric oxide synthase expression and functional response to nitric oxide are both important modulators of circulating angiogenic cell response to angiogenic stimuli / C. Heiss, A. Schanz, N. Amabile [et al.] // Arteriosclerosis, Thrombosis, and Vascular Biology. - 2010. - Vol. 30 (11). P. 2212-2218.

36. Riccio D. Nitric oxide release: partl. Macromolecular scaffolds / D. Riccio, M. Schoenfisch // Chem. Soc. Rev. 2012. - Vol. 41. - P. 3731-3744.

37. Rubanyi G. M. The role of endothelium in cardiovascular homeostasis and diseases / G. M. Rubanyi // J. Cardiovasc. Pharmacol. - 2013. - Vol. 22 (4). - P. S1-S4.

38. Stoica A. L. Interleukin-6 and interleukin-10 gene polymorphism, endothelial dysfunction, and prognosis in patients with peripheral arterial disease / A. L. Stoica // J. Vasc. Surg. - 2010. - Vol. 52 (1). - P. 103-109.

39. The role of nitric oxide on endothelial function / D. Tousoulis, A. Kampoli, C. Tentolouris [et al.] // Curr. Vasc. Pharmacol. - 2012. - Vol. 10. - P. 4-18.

40. The endothelium: influencing vascular smooth muscle in many ways / C. Triggle, S. Samuel, S. Ravishankar [et al.] // Can. J. Physiol. Pharmacol. - 2012. - Vol. 90. P. 713-738.

41. Van Hinsbergh V. W. Endothelium - role in regulation of coagulation and inflammation / V. W. Van Hinsbergh // Semin. Immunopathol. - 2012. - Vol. 34. - P. 93-106.

functional properties and its dysfunction]. Infektsiini khvoroby - Infectious Diseases, 1, 66-71 [in Ukrainian].

6. Dieltsova, O., Herashchenko, S., \& Chaikovskyi, Yu. (2014). Stovburovi klityny stinky krovonosnykh sudyn [Stem cells of the blood vessel wall]. Ukrainskyi kardiolohichnyi zhurnal - Ukrainian Cardiac Journal, 1, 97-101 [in Ukrainian].

7. Zagidullin, N.Sh., Valeyeva, K.F., \& Gassanov, N. (2010). Znacheniye disfunktsii endoteliya pri serdechno-sosudistykh zabolevaniyakh i metody yeye medikamentoznoy korrektsii [The value of endothelial dysfunction in cardiovascular diseases and methods of its medical correction]. Kardiologiya - Cardiology, 5, 54-60 [in Russian].

8. Zaremba, Ye, \& Zimba, O. (2009). Endotelialna dysfunktsiia u khvorykh na revmatyzm iz nedyferentsiiovanoiu dysplaziieiu spoluchnoi tkanyny [Endothelial dysfunction in patients with rheumatism with undifferentiated connective tissue dysplasia]. Ukrainskyi revmatolohichnyi zhurnal Ukrainian Rheumatology Journal, 4 (38), 32-34 [in Ukrainian].

9. Kapelko, V.I. (2011). Diastolicheskaya disfunktsiya [Diastolic dysfunction]. Kardiologiya - Cardiology, 1, 79-90 [in Russian].

10. Ketlinskiy, S.A., \& Simbirtsev, A.S. (2008). Tsitokiny [Cytokines]. Saint-Petersburg: Foliant [in Russian].

11. Lyusov, V.A., Metelskaya, V.A., \& Oganov, R.G. (2011). Uroven oksida azota v syvorotke perifericheskoy 
Огляди літератури, оригінальні дослідження, погляд на проблему, випадок з практики, короткі повідомлення

krovi bolnykh s razlichnoy tyazhestyu arterialnoy gipertenzii [The level of nitric oxide in the serum of peripheral blood of patients with various severity of arterial hypertension]. Kardiologiya - Cardiology, 12, 23-28 [in Russian].

12. Malaya, L., Korzh, A.N., \& Balkovaya, L.B. (2002). Endotelialnaya disfunktsiya pri patologii serdechno-sosudistoy sistemy [Endothelial dysfunction in the pathology of the cardiovascular system]. Kharkov: Torsing [in Russian].

13. Maksimova, L., Milner, I., Tolstoy, V., \& Levada, I. (2008). Endotelialnaya disfunktsiya sosudov i yeye korrektsiya pri khronicheskoy revmaticheskoy bolezni serdtsa [Endothelial vascular dysfunction and its correction in chronic rheumatic heart disease]. Aktualni problemy suchasnoi medytsyny - Actual Problems of Modern Medicine, 8, 4 (52), 121-124 [in Russian].

14. Malyarska, N., \& Kalinichenko, M. (2017). Endotelialna dysfunktsiia yak universalnyi predyktor rozvytku sertsevo-sudynnoi patolohii ta mozhlyvosti yii korektsii v praktytsi simeynoho likaria [Endothelial dysfunction as a universal predictor of cardiovascular pathology development and its correction in family physician practice]. Liky Ukrainy-Medicines of Ukraine, 1 (207), 38-41 [in Ukrainian].

15. Paleyev, F.N. (2010). Izmeneniye interleykina-6 pri razlichnykh formakh ishemicheskoy bolezni serdtsa [Change in interleukin-6 in various forms of coronary heart disease]. Kardiologiya - Cardiology, 2, 69-72 [in Russian].

16. Sadlyak, O.V. (2013). Endoteliy yak rehulyator imunnykh, zapalnykh ta vilnoradykalnykh protsesiv, oposeredkovanykh systemoyu L-arhinin-oksyd azotu [Endothelium as a regulator of immune, inflammatory and free radical processes mediated by the L-arginine-nitric oxide system]. Medychna khimiia-Medical Chemistry, 15, 4, 96-99 [in Ukrainian].

17. Sadykova, D., Sergeyeva, Ye., \& Aflyatumova, G. (2014). Znacheniye disfunktsii endoteliya pri arterialnoy gipertenzii u detey i podrostkov [Importance of endothelial dysfunction in arterial hypertension in children and adolescents]. Prakticheskaya meditsina - Practical Medicine, 9 (85), 24-27 [in Russian].

18. Salyutin, R., Dombrovskyi, D., Palianytsia, S., Shablii, V., Borys, R., Lobyntseva, H., \& Buslovych, O. (2013). Zminy endoteliotsytiv kapiliariv ta histolohichnoi struktury ishemizovanoi ta intaktnoi miazovoi tkanyny pislia transplantatsii hemopoetychnykh stovburovykh klityn fetalnoi pechinky liudyny v eksperymenti in vivo [Changes of capillary endothelial cells and histological structure of ischemic and intact muscle tissue after transplantation of human hematopoietic stem cells in human fetal liver and human liver liver]. Bukovynskyi medychnyi visnyk - Bukovynian Medical Bulletin, 17, 1 (65), 101-105 [in Ukrainian].

19. Sukmanova, I.A., Yakhontov, D.A., \& Pospelova, T.I. (2010). Pokazateli funktsii endoteliya, morfofunktsionalnyye parametry serdtsa i metabolicheskiy status pri diastolicheskoy khronicheskoy serdechnoy nedostatochnosti u bolnykh raznykh vozrastnykh grupp [Endothelial function indices, morphofunctional parameters of the heart and metabolic status in patients with diastolic chronic heart failure in different age groups]. Kardiologiya $i$ serdechno-sosudistaya khirurgiya - Cardiology and Cardiovascular Surgery, 3, 3, 72-75 [in Russian].

20. Taktashov, G.S. (2015). Rol endotelialnoy disfunktsii sosudov pri narusheniyakh respiratornykh funktsiy u bolnykh khronicheskoy revmaticheskoy boleznyu serdtsa
[The role of vascular endothelial dysfunction in respiratory disorders in patients with chronic rheumatic heart disease]. Aktualni problemy suchasnoi medytsyny-Actual Problems of Modern Medicine, 15, 4 (52), 120-124 [in Russian].

21. Shlyakhov, N.V., Budreyko, O.A., \& Chumak, S.O. (2012). Sudynnyi endotelialnyi faktor rostu yak marker sudynnykh dysfunktsii u ditey z ozhyrinniam [Vascular endothelial growth factor as a marker of vascular dysfunction in children with obesity]. Problemy endokrynnoi patolohii Problems of Endocrine Pathology, 1, 26-32 [in Ukrainian].

22. Amir, O. (2010). Circulating interleukin-10: association with higher mortality in systolic heart failure patients with elevated tumor necrosis factor-alpha. Isr. Med. Assoc. J., 12, 3, 158-162.

23. Punshon, G.I., Vara, D.S., Sales, K.M., \& Seifalian, A.M. (2011). A novel method for the extraction and culture of progenitor stem cells from human peripheral blood for use in regenerative medicine. Biotechnol. Appl. Biochem., 55 (8), 328-334.

24. Volpe, M., Battistoni, A., Tocci, G., Rosei, E.A., Catapano, A.L., Coppo, R., ..., \& Mancia, G. (2012). Cardiovascular risk assessment beyond systemic coronary risk estimation: a role for organ damage markers. J. Hypertens., 30, 1056-1064.

25. Dignat-George, F., \& Boulanger, C.M. (2011). The many faces of endothelial microparticles. Arteriosclerosis, Thrombosis, and Vascular Biology, 31 (1), 27-33.

26. Feletou, M., Kohler, R., \& Vanhoutte, P.M. (2012). Nitric oxide: orchestrator of endothelium-dependent responses. Ann. Med., 44, 694-716.

27. Forstermann, U., \& Sessa, W.C. (2012). Nitric oxide synthases: regulation and function. Eur. Heart J., 33, 829-837.

28. Higashi, Y., Kihara, Y., \& Noma, K. (2012). Endothelial dysfunction and hypertension in aging. Hypertens. Res., 35, 1039-1047.

29. Hirata, Y., Nagata, D., \& Suzuki, E. (2010). Diagnosis and treatment of endothelial dysfunction in cardiovascular disease. Int. Heart J., 51 (1), 1-6.

30. Ward, A.M., Takahashi, O., Stevens, R., \& Heneghan, C. (2012). Home measurement of blood pressure and cardiovascular disease: systematic review and meta-analysis of prospective studies. J. Hypertens., 30, 449-456.

31. Iantorno, M., Campia, U., Di Daniele, N., Nistico, S., Forleo, G.B., Caroillo, C., \& Tesauro, M. (2014). Gut hormones and endothelial dysfunction in patients with obesity and diabetes. Int. J. Immunopathol. Pharmacol., 27, 3, 433-436.

32. Joseph, N., Madi, D., Kumar, G.S., Nelliyanil, M., Saralaya, V., \& Rai, S. (2013). Clinical spectrum of rheumatic fever and rheumatic heart disease: a 10 year experience in an urban area of South India. N. Am. J. Med. Sci., 5, 11, 647-652.

33. Leask, R.L., Jain, N., \& Butany, J. (2009). Endothelium and valvular diseases of the heart. Microsc. Res. Tech., $60,2,129-137$.

34. Меera, K.S., \& Marcus S.R. (2012). Endothelial dysfunction and oxidative stress in hypertension. Asian. J. Med. Res., 1 (3), 84-89.

35. Heiss, C., Schanz, A., Amabile, N., Jahn, S., Chen, Q., Wong, M.L., ... \& Springer, M.L. (2010). Nitric oxide synthase expression and functional response to nitric oxide are both important modulators of circulating angiogenic cell response to angiogenic stimuli. Arteriosclerosis, Thrombosis, and Vascular Biology, 30 (11), 2212-2218. 
Огляди літератури, оригінальні дослідження, погляд на проблему, випадок з практики, короткі повідомлення

36. Riccio, D., \& Schoenfisch, M. (2012). Nitric oxide release: part I. Macromolecular scaffolds. Chem. Soc. Rev., 41, 3731-3744.

37. Rubanyi, G.M. (2013). The role of endothelium in cardiovascular homeostasis and diseases. J. Cardiovasc. Pharmacol., 22, 4, S1-S4.

38. Stoica, A.L. (2010). Interleukin-6 and interleukin-10 gene polymorphism, endothelial dysfunction, and prognosis in patients with peripheral arterial disease. J. Vasc. Surg., 52, 1, 103-109.
39. Tousoulis, D., Kampoli, A.M., Tentolouris, C., Papageorgiou, N., \& Stefanadis, C. (2012). The role of nitric oxide on endothelial function. Curr. Vasc. Pharmacol., 10, 4-18.

40. Triggle, C.R., Samuel, S.M., Ravishankar, S., Marei, I., Arunachalam, G., \& Ding, H. (2012). The endothelium: influencing vascular smooth muscle in many ways. Can. J. Physiol. Pharmacol., 90, 713-738.

41. Van Hinsbergh, V.W. (2012). Endothelium - role in regulation of coagulation and inflammation. Semin. Immunopathol., 34, 93-106.

\title{
РОЛЬ ДИСФУНКЦИИ ЭНДОТЕЛИЯ В ФОРМИРОВАНИИ ПОРОКОВ КЛАПАНОВ СЕРДЦА
}

๑Л. Я. Федонюк

\author{
Тернопольский национальный медицинский университет имени И. Я. Горбачевского Мз Украины
}

РЕЗЮМЕ. В настоящее время установлено, что эндотелий представляет собой динамическую систему, которая может меняться, а ее структурно-функциональные свойства тесно связаны с многочисленными локальными, системными факторами, а также особенностями структурной организации. Повреждение или активация эндотелиоцитов нарушает нормальные регуляторные механизмы и приводит к фенотипическим изменениям, которые в целом определяются как эндотелиальная дисфункция. Эндотелиальная дисфункция представляет собой нарушение взаимоотношений между факторами, которые поддерживают гомеостаз и регулируют многочисленные функции эндотелия.

Цель - привести современные сведения о структурно-функциональных свойствах эндотелия и патогенезе эндотелиальной дисфункции; осветить взаимосвязанные влияния вазоактивных субстанций эндотелиального происхождения, прежде всего оксида азота.

К наиболее значимым механизмам эндотелиальной дисфункции относится нарушение метаболизма L-аргинин - оксид азота (NO), который является основной эффекторной молекулой, продуцируемой эндотелиоцитами. Изменения функции сосудистого эндотелия могут быть следствием как уменьшения синтеза NO эндотелиальными клетками, так и активации процессов его деградации в условиях оксидативного стресса.

Нарушение функционального состояния эндотелия описаны при различных патологических состояниях, таких как атеросклероз, артериальная гипертензия, гиперхолестеринемия, хроническая сердечная недостаточность, сахарный диабет. Эндотелиальная дисфункция практически закономерно развивается при ревматических болезнях, а также при инфекционном эндокардите, что является одной из главных причин кардиоваскулярных осложнений заболеваний.

КЛЮЧЕВЫЕ СЛОВА: эндотелий; кровеносные сосуды; пороки клапанов сердца.

\section{THE ROLE OF THE ENDOTHELIAL DYSFUNCTION IN THE FORMATION OF THE HEART VALVES DEFECTS}

\section{Horbachevsky Ternopil National Medical University}

@L. Ya. Fedoniuk

SUMMARY. It is known, that the endothelium is a dynamic system that can be changed, and its structural and functional properties are closely related to numerous local, systemic factors, as well as peculiarities of the structural organization. Damage or activation of endothelial cells disrupts normal regulatory mechanisms and leads to phenotypic changes, generally defined as endothelial dysfunction. Endothelial dysfunction is a disruption of the relationship between factors that support homeostasis and regulate numerous endothelial functions.

The aim - to present current information on the structural and functional properties of endothelium and the pathogenesis of endothelial dysfunction; to clarify the interdependent effects of vasoactive substances of endothelial origin, primarily nitrogen oxide.

The most significant mechanisms of endothelial dysfunction include impaired metabolism of L-arginine nitric oxide (NO), which is the main effector molecule produced by endothelial cells. Changes in vascular endothelial function may be due both to a decrease in NO synthesis by endothelial cells and to the activation of its degradation processes under conditions of oxidative stress.

Disorders of the functional state of the endothelium have been described in various pathological conditions, such as atherosclerosis, arterial hypertension, hypercholesterolemia, chronic heart failure, diabetes. Endothelial dysfunction almost naturally develops in rheumatic diseases, as well as in infectious endocarditis as one of the main causes of cardiovascular complications of diseases.

KEY WORDS: endothelium; blood vessels; heart valve defects. 